\title{
32. DATA REPORT: CHEMICAL ANALYSES OF THE LEG 140 REFERENCE SAMPLE ${ }^{1}$
}

\author{
Joel W. Sparks ${ }^{2}$ and Evelyn Zuleger ${ }^{3}$
}

\section{INTRODUCTION}

To facilitate comparisons among various Leg 140, Hole 504B geochemical data sets, an inter-laboratory geochemical reference sample was prepared from approximately $1 \mathrm{~kg}$ of moderately phyric, plagioclase-clinopyroxene-olivine diabase. This sample was taken from a single "junk basket" piece (Sample 140-504B-182M-3, 7-20 $\mathrm{cm}$, referred to here as BAS-140) collected from the sheeted dike section of Hole $504 \mathrm{~B}\left(1^{\circ} 13.611^{\prime} \mathrm{N}, 83^{\circ} 43.818^{\prime} \mathrm{W}\right)$, at an approximate depth of $1622 \mathrm{mbsf}$.

\section{SAMPLE PREPARATION}

Aboard the JOIDES Resolution, the recovered sample was sawn and then broken into smaller pieces with a water-cooled diamond saw and steel hammer. Excessively altered material, hammer and saw marks were removed by wet-grinding on a diamond abrasive wheel. The sample was then sonicated in distilled water and methanol for 10 min, and dried at $110^{\circ} \mathrm{C}$ for more than 2 hrs. Rock chips larger than 1 $\mathrm{cm}$ in diameter were placed between two disks of Delrin plastic and crushed in a hydraulic press so they could fit into the grinding vessel. The total sample was then divided into $50 \mathrm{~g}$ to $80 \mathrm{-g}$ batches and ground for about $1.5 \mathrm{~min}$ per batch $(<30 \mu \mathrm{m}$ grain size $)$ in a tungsten carbide (WC) shatterbox. Accumulated batches of sample powder were homogenized in a 1-gal plastic bag for about $1 \mathrm{hr}$ and then distributed in roughly $30 \mathrm{-g}$ aliquants to interested members of the shipboard party.

Grinding samples in a WC container introduces significant amounts of $\mathrm{W}, \mathrm{Co}$, Ta, and to a lesser extent $\mathrm{Nb}$, and possibly $\mathrm{Zn}$ (Thompson and Bankston, 1970; Joron et al., 1980; Hickson and Juras, 1986; Frey et al., 1991). Of these elements, only Nb, Co, and $\mathrm{Zn}$ are reported here. The amount of $\mathrm{Nb}$ contamination appears to be much less than 1 ppm (Sparks, this volume), and there is no significant indication that this kind of contamination has affected sample homogeneity.

\section{RESULTS}

Tables 1 and 2 list the individual results from the eight laboratories that contributed to this report. It is not our intention to present any of these results as either "preferred" or "recommended" values. These values are for comparison purposes only. The various laboratories and associated Leg 140 scientists are: GeoForschungsZentrum Potsdam (GFZ) - E. Zuleger; Georgia State University (GSU) - D.A. Vanko; Shipboard Scientific Party (LEG140); Justus-Liebig-Universität (JLU) - E. Zuleger; University of Michigan (MICH) - J.C. Alt; Université Paris (PAR) - P. Agrinier; Stanford University (STAN) J.W. Sparks; University of Tasmania (TAS) - A.W. McNeill. The analytical techniques employed at each laboratory are given in the

\footnotetext{
'Erzinger, J., Becker, K., Dick, H.J.B., and Stokking. L.B. (Eds.), 1995. Proc, ODP, Sci. Results, 137/140: College Station, TX (Ocean Drilling Program).

${ }^{2}$ Department of Geology, Stanford University, Stanford, CA 94305 , U.S.A.

${ }^{3}$ Institut für Geowissenschaften und Lithosphärenforschung. Justus-Liebig-Universität, D-39390 Giessen, Federal Republic of Germany. (Current address: GeoForschungsZentrum, Telegrafenberg A50, D-14473 Potsdam, Federal Republic of Germany.)
}

notes below each table. Estimated values of analytical precision are listed along with the individual results.

Major element analyses $\left(\mathrm{SiO}_{2}\right.$ through $\mathrm{P}_{2} \mathrm{O}_{5}$, Table 1) were corrected for loss on ignition (LOI), and reported on an anhydrous basis. The left-most column of numbers represents the unweighted mean concentration and standard deviation of multiple analyses. Where there is only one analysis for a given element, that analysis is given as the mean. The standard deviations of the mean for oxides $\mathrm{SiO}_{2}$ through $\mathrm{P}_{2} \mathrm{O}_{5}$ are all similar to, or less than, the values for analytical error. This remarkably strong agreement demonstrates there are no significant inter-laboratory calibration biases, or major element heterogeneities. The similarity of analytical techniques and wide use of commonly reported international geostandards no doubt contributed to this agreement. Each major element analysis was determined by $\mathrm{X}$-ray fluorescence (XRF) on Li-borate glass discs.

Trace element concentrations (Table 2), although in many cases very precise, exhibit a wider range of values resulting from interlaboratory calibration biases, differing analytical methods, and extremely low concentrations of highly incompatible elements such as $\mathrm{Nb}$ and $\mathrm{Rb}$. Overall, there is good agreement between analyses of $\mathrm{Ni}$, $\mathrm{Cu}, \mathrm{Ga}, \mathrm{Sr}$, and $\mathrm{Y}$; moderate agreement between $\mathrm{Zr}$ analyses; and moderate to poor agreement for many of the REE as well as S, V, Cr, and $\mathrm{Zn}$ values. Sample homogeneity on the trace element scale is not a likely factor in many of the discrepancies. The error values reported by LEG140 represent the standard deviation of the mean $(1 \sigma)$ for six separate splits of BAS-140 (Shipboard Scientific Party, 1992). For each element, this variation is about the same as the estimated analytical precision, further demonstrating the homogeneity of the sample (we are assuming that these particular elements serve as appropriate indicators to the distribution of REE; however, they may not apply to S).

It is beyond the scope of this report to judge the accuracy of these analyses. We leave it up to the reader to make further comparisons and inquiries, as needed.

\section{ACKNOWLEDGMENTS}

The authors would like to thank both J.F. Allan and J.A. Erzinger for their thorough reviews, and all the analysts who contributed to this report.

\section{REFERENCES}

Alt, J.C., Anderson, T.F., and Bonnell, L., 1989. The geochemistry of sulfur in a $1.3 \mathrm{~km}$ section of hydrothermally altered oceanic crust, DSDP Hole 504B. Geochim. Cosmochim. Acta, 53:1011-1023.

Coleman, M.L., Shepherd, T.J., Durham, J.J., Rouse, J.E., and Moore, G.R., 1982. Reduction of water with zine for hydrogen isotope analysis. Anal. Chem., 54:993-995.

Frey, F.A., Jones, W.B., Davies, H., and Weis, D., 1991. Geochemical and petrologic data for basalts from Sites 756, 757, and 758: implications for the origin and evolution of the Ninetyeast Ridge. In Weissel, J., Peirce, J., Taylor, E., Alt, J., et al., Proc. ODP, Sci. Results, 121: College Station, TX (Ocean Drilling Program), 611-659.

\footnotetext{
Abbreviations for names of organizations and publications in ODP reference lists follow the style given in Chemical Abstracts Service Source Index (published by American Chemical Society).
} 
Hickson, C.J., and Juras, S.J., 1986. Sample contamination by grinding. Can. Mineral., 24:585-589.

Joron, J.L., Briqueu, L., Bougault, H., and Treuil, M., 1980. East Pacific Rise, Galapagos spreading center and Siqueiros Fracture Zone, Deep Sea Drilling Project Leg 54: hygromagmaphile elements-a comparison with the North Atlantic. In Rosendahl, B.R., Hekinian, R., et al., Init. Repts. DSDP, 54: Washington (U.S. Govt. Printing Office), 725-735.

LaTour, T.E., 1989. Analysis of rocks using X-ray fluorescence spectrometry. Rigaku J., 6:3-9.

Norrish, K., and Chappell, B., 1977. X-ray fluorescence spectrometry. In Zussman, J. (Ed.), Physical Methods in Determinative Mineralogy: New York (Academic Press), 201-272.
Shipboard Scientific Party, 1992. Site 504. In Dick, H.J.B., Erzinger, J., Stokking, L.B., et al., Proc. ODP, Init. Repts., 140: College Station, TX (Ocean Drilling Program), 37-200.

Thompson, G., and Bankston, D.C., 1970. Sample contamination from grinding and sieving determined by emission spectroscopy. Appl. Spectros., 24:210-219.

Date of initial receipt: 8 July 1993

Date of acceptance: 25 January 1994

Ms 137/140SR-041

Table 1. Major and minor oxide analyses of Leg 140 reference sample BAS-140.

\begin{tabular}{|c|c|c|c|c|c|c|c|}
\hline & \multirow[b]{2}{*}{ Mean $\pm 1 \sigma$} & \multicolumn{6}{|c|}{ Laboratories" } \\
\hline & & GSU & LEGI40 & JLU & STAN & TAS & PAR \\
\hline $\mathrm{SiO}_{2}(\mathrm{wt} \%)$ & $50.5 \pm 0.1$ & $50.3 \pm 0.2$ & $50.6 \pm 0.1$ & $50.6 \pm 0.2$ & $50.6 \pm 0.2$ & $50.4 \pm 0.1$ & \\
\hline $\mathrm{TiO}_{2}$ & $0.98 \pm 0.01$ & $0.98 \pm 0.01$ & $0.97 \pm 0.01$ & $1.00 \pm 0.01$ & $0.99 \pm 0.01$ & $0.97 \pm 0.01$ & \\
\hline $\mathrm{Al}_{2} \mathrm{O}_{3}$ & $14.6 \pm 0.03$ & $14.53 \pm 0.05$ & $14.58 \pm 0.05$ & $14.6 \pm 0.1$ & $14.58 \pm 0.09$ & $14.57 \pm 0.03$ & \\
\hline $\mathrm{Fe}_{2} \mathrm{O}_{3} * \mathrm{~b}$ & $11.1 \pm 0.10$ & $11.09 \pm 0.05$ & $11.15 \pm 0.07$ & $11.3 \pm 0.1$ & $11.08 \pm 0.05$ & $11.04 \pm 0.06$ & \\
\hline $\mathrm{MnO}$ & $0.19 \pm 0.005$ & $0.18 \pm 0.005$ & $0.18 \pm 0.002$ & $0.19 \pm 0.005$ & $0.19 \pm 0.003$ & $0.19 \pm 0.005$ & \\
\hline $\mathrm{MgO}$ & $8.15 \pm 0.09$ & $8.22 \pm 0.04$ & $8.01 \pm 0.05$ & $8.22 \pm 0.05$ & $8.14 \pm 0.08$ & $8.19 \pm 0.02$ & \\
\hline $\mathrm{CaO}$ & $12.4 \pm 0.10$ & $12.28 \pm 0.02$ & $12.51 \pm 0.03$ & $12.5 \pm 0.0$ & $12.41 \pm 0.04$ & $12.32 \pm 0.01$ & \\
\hline $\mathrm{Na}_{2} \mathrm{O}$ & $1.84 \pm 0.04$ & $1.86 \pm 0.04$ & $1.85 \pm 0.05$ & $1.77 \pm 0.02$ & $1.85 \pm 0.03$ & $1.87 \pm 0.05$ & \\
\hline $\mathrm{K}_{2} \mathrm{O}$ & $0.01 \pm 0.004$ & $0.01 \pm 0.005$ & $0.004 \pm 0.003$ & $<L^{2} D^{6}$ & & <LLD & \\
\hline $\mathrm{P}_{2} \mathrm{O}_{5}$ & $0.08 \pm 0.01$ & $0.08 \pm 0.005$ & $0.06 \pm 0.01$ & $0.08 \pm 0.004$ & $0.07 \pm 0.002$ & $0.09 \pm 0.01$ & \\
\hline Total (anhydrous) & 99.9 & 99.6 & 99.9 & 100.3 & 99.9 & 99.7 & \\
\hline $\mathrm{Fe}_{2} \mathrm{O}_{3}$ & $2.72 \pm 0.12$ & & & $2.72 \pm 0.12$ & & & \\
\hline $\mathrm{FeO}$ & $7.72 \pm 0.06$ & & & $7.72 \pm 0.06$ & & & \\
\hline $\mathrm{LOI}^{4}$ & $0.59 \pm 0.13$ & & & & 0.50 & 0.68 & \\
\hline $\mathrm{H}_{2} \mathrm{O}^{+}$ & $1.12 \pm 0.14$ & & $1.25 \pm 0.06$ & 1.15 & & & $0.97 \pm 0.08$ \\
\hline $\mathrm{CO}_{2}$ & $0.05 \pm 0.03$ & & $0.03 \pm 0.01$ & 0.07 & & & \\
\hline
\end{tabular}

Note: Blank spaces $=$ not determined.

"Laboratories, associated techniques and references (as given by analysts) = GSU: XRF - major elements (LaTour, 1989); JLU: XRF - major elements, Karl Fisher titration - $\mathrm{H}_{2} \mathrm{O}^{+}$. infrared spectrophotometry $-\mathrm{CO}_{2}$ (Zuleger et al., this volume); LEG140: XRF - major elements, gas chromatography $(\mathrm{GC})-\mathrm{H}_{2} \mathrm{O}^{+}$and $\mathrm{CO}_{2}$ (Shipboard Scientific Party, 1992); PAR: manometric determination following sample fusion $-\mathrm{H}_{2} \mathrm{O}^{+}$(Coleman et al.,1982); STAN: XRF - major elements (Sparks, this volume); TAS: XRF — major elements (Norrish and Chappell. 1977)

${ }^{\mathrm{b}} \mathrm{Fe}_{2} \mathrm{O}_{3}$ " = Total iron reported as $\mathrm{Fe}_{2} \mathrm{O}_{3}$.

${ }^{c} \angle \mathrm{LLD}=$ Less than the lower limit of detection.

${ }^{\triangleleft} \mathrm{LOI}=$ Loss on ignition. 
Table 2. Trace element and isotope analyses of Leg 140 reference sample BAS-140.

\begin{tabular}{|c|c|c|c|c|c|c|c|c|}
\hline & \multicolumn{8}{|c|}{ Laboratories } \\
\hline & LEG140 & JLU (XRF) & JLU (ICPES) & STAN & GFZ & TAS & PAR & $\mathrm{MICH}$ \\
\hline $\mathrm{Li}$ (ppm) & & & & & $1.2 \pm 0.1$ & & & \\
\hline $\mathrm{S}$ & & $954 \pm 7$ & & $887 \pm 4$ & & & & $860 \pm 50$ \\
\hline $\mathrm{Cl}$ & & & & $87 \pm 4$ & & & & \\
\hline Sc & & & & & $43 \pm 3$ & 40.7 & & \\
\hline V & $331 \pm 5$ & & & $342 \pm 2$ & & & & \\
\hline $\mathrm{Cr}$ & $175 \pm 1$ & $194 \pm 2$ & & $192 \pm 2$ & $186 \pm 10$ & 185 & & \\
\hline Co & & & & & $55 \pm 4$ & & & \\
\hline $\mathrm{Ni}$ & $84 \pm 0.5$ & $81 \pm 2$ & & $85 \pm 1$ & $85 \pm 3$ & & & \\
\hline $\mathrm{Cu}$ & $83 \pm 0.5$ & $83 \pm 2$ & & $84 \pm 1$ & $81 \pm 2$ & & & \\
\hline $\mathrm{Zn}$ & $76 \pm 0.4$ & $78 \pm 1$ & & $85 \pm 1$ & $80 \pm 2$ & & & \\
\hline $\mathrm{Ga}$ & & $16 \pm 1$ & & $15.6 \pm 0.4$ & $15.5 \pm 0.3$ & & & \\
\hline $\mathrm{Rb}$ & $<0.4$ & & & $<0.5$ & $0.06 \pm 0.005$ & & & \\
\hline $\mathrm{Sr}$ & $44.5 \pm 0.3$ & $47 \pm 1$ & & $45.5 \pm 0.4$ & $44 \pm 1$ & & & \\
\hline $\mathrm{Y}$ & $25.9 \pm 0.2$ & $27 \pm 1$ & $24.5 \pm 0.7$ & $26.6 \pm 0.2$ & $24 \pm 1$ & & & \\
\hline $\mathrm{Zr}$ & $45.4 \pm 0.5$ & $49 \pm 0.5$ & & $44.8 \pm 0.3$ & & & & \\
\hline $\mathrm{Nb}$ & $0.5 \pm 0.1$ & $<5$ & & $<0.3$ & $0.5 \pm 0.1$ & & & \\
\hline $\mathrm{La}$ & & & $1.0 \pm 0.1$ & & $0.92 \pm 0.02$ & 2.04 & & \\
\hline $\mathrm{Ce}$ & & & $4.8 \pm 0.4$ & & $3.73 \pm 0.13$ & 3.85 & & \\
\hline $\operatorname{Pr}$ & & & & & $0.77 \pm 0.04$ & & & \\
\hline $\mathrm{Nd}$ & & & $4.5 \pm 0.1$ & & $4.9 \pm 0.1$ & 5.45 & & \\
\hline $\mathrm{Sm}$ & & & $2.0 \pm 0.1$ & & $2.08 \pm 0.05$ & 2.07 & & \\
\hline Eu & & & $0.61 \pm 0.01$ & & $0.78 \pm 0.03$ & 0.7 & & \\
\hline Gd & & & $3.0 \pm 0.1$ & & $3.2 \pm 1$ & & & \\
\hline $\mathrm{Tb}$ & & & & & $0.63 \pm 0.01$ & 0.56 & & \\
\hline Dy & & & $3.5 \pm 0.1$ & & $4.5 \pm 0.1$ & & & \\
\hline Ho & & & $0.87 \pm 0.03$ & & $0.97 \pm 0.03$ & 0.94 & & \\
\hline Er & & & $2.6 \pm 0.0$ & & $2.9 \pm 0.1$ & & & \\
\hline $\mathrm{Tm}$ & & & & & $0.44 \pm 0.02$ & & & \\
\hline $\mathrm{Yb}$ & & & $2.5 \pm 0.0$ & & $3.0 \pm 0.1$ & 2.88 & & \\
\hline $\mathrm{Lu}$ & & & $0.40 \pm 0.01$ & & $0.42 \pm 0.02$ & 0.46 & & \\
\hline $\mathrm{Hf}$ & & & & & $1.1 \pm 0.2$ & 1.39 & & \\
\hline $\mathrm{Bi}$ & & & & & $0.02 \pm 0.001$ & & & \\
\hline Th & & & & & $0.025 \pm 0.006$ & & & \\
\hline U & & & & & $0.008 \pm 0.002$ & & & \\
\hline$\delta^{18} \mathrm{O}(\% 0)$ & & & & & & & $4.34 \pm 0.1$ & \\
\hline$\delta \mathrm{D}$ & & & & & & & $-44 \pm 2$ & \\
\hline
\end{tabular}

* Laboratories, associated techniques and references (as given by analysts) = GFZ: inductively coupled plasma mass spectrometry (Zuleger and Erzinger, this volume); LEG140: XRF (Shipboard Scientific Party, 1992); STAN: XRF (Sparks, this volume); JLU: $\mathrm{XRF}-\mathrm{Zr}, \mathrm{Y}, \mathrm{Sr}, \mathrm{Zn}, \mathrm{Cu}, \mathrm{Ni}$, and $\mathrm{Cr}$, Leco Analyzer - S, inductively coupled plasma emission spectrometry - rare earth elements and $\mathrm{Y}$ (Zuleger and Erzinger, this volume); $\mathrm{MICH}$ : coulorimetric titration - S as sulfide (Alt et al., 1989); TAS: instrumental neutron activation analysis (Becquerel Laboratories, Sydney, Australia); PAR: mass spectrometry (Coleman et al., 1982). 